\title{
FISIOTERAPI DAN TERAPI LATIHAN PADA OSTEOARTRITIS
}

\author{
Oleh: Novita Intan Arovah
}

Dosen Jurusan Pendidikan Kesehatan dan Rekreasi FIK UNY

\section{Abstrak}

Osteoartritis merupakan gangguan degenerasi struktur tulang rawan pada persendian. Faktor epidemiologis yang meningkatkan risiko terjadinya osteoartritis antara lain: cedera sendi, obesitas, dan usia lanjut. Olahragawan merupakan salah satu kelompok profesi yang berisiko tinggi mengalami osteoartritis karena pada olahragawan sering terjadi penggunaan persendian yang berlebihan yang dapat mengakibatkan cedera pada persendian.

Dewasa ini, manajemen osteoartritis tidak lagi berpusat pada terapi farmakologis dan bedah, akan tetapi cenderung dikombinasikan dengan fisioterapi dan terapi latihan. Fisioterapi yang sering dilakukan pada manajemen osteoartritis antara lain meliputi: (1) thermal dan hydrotherapy, (2) electromagnetic therapy, dan (3) manual therapy. Terapi latihan pada osteoartritis dilakukan dalam lima tahap. Tahap I meliputi latihan terkontrol sedangkan pada tahap II dan III meliputi latihan yang bersifat open kinetic-chain sampai dengan closed kinetic-chain. Tahap IV difokuskan pada latihan untuk meningkatkan kemampuan fisik. Pada tahap V (fase pemeliharaan) dilakukan latihan rutin untuk memperkuat otot penunjang persendian sehingga meminimalkan risiko terjadinya cedera ulang.

Secara umum, kombinasi short wave diathermy dan cold therapy merupakan program fisioterapi yang direkomendasikan pada rehabilitasi osteoartritis. Terapi latihan yang dapat dilakukan berupa latihan fleksibilitas untuk memulihkan jangkauan sendi, strengthening untuk memulihkan kekuatan, dan

Fisioterapi dan Terapi Latihan Pada Osteoarthritis (Novita Intan Arovah) 
latihan aerobik untuk meningkatkan kebugaran secara keseluruhan.

Kata kunci: osteortritis, fisioterapi

Osteoarthritis (OA) merupakan jenis gangguan persendian yang paling sering dijumpai (Cote, 2001: 495). Saxon et.al (1999: 124) memperkirakan, sekitar sepertiga orang yang berusia 25 sampai dengan 75 tahun mempunyai gambaran osteoartritis sendi pada pemeriksaan radiologis. Lutut merupakan persendian yang paling sering mengalami OA dan merupakan jenis OA yang paling berkaitan dengan gejala nyeri dan disabilitas (Baker, 2000: 217). WHO melaporkan bahwa OA lutut merupakan penyebab disabilitas keempat pada perempuan dan kedelapan pada laki-laki (Cote, 2001: 496).

Secara umum manajemen OA dibedakan menjadi pengobatan konservatif dan bedah. Terapi konservatif mempergunakan obat penghilang rasa nyeri jenis non steroid anti inflammatory drugs (NSAIDs) seperti acetaminophen, ibuprofen maupun obat jenis kortikosteroid dan narkotik. Beberapa diet makanan kaya glukosamine dan chondroitin juga dipercaya dapat mempercepat penyembuhan OA (Petty, 2004: 154). Dewasa ini, fisioterapi dan terapi latihan disebutkan dapat membantu proses rehabilitasi penderita OA (Deyle et.al, 2000: 174). Makalah ini terutama akan membahas jenis fisioterapi dan terapi latihan yang dapat digunakan dalam manajemen OA, dengan terlebih dahulu membahas mekanisme, faktor risiko dan kriteria diagnosis terjadinya $\mathrm{OA}$.

MEDIKORA Vol.III, No 1, April 2007:18-41 


\section{OSTEOARTRITIS}

\section{Patofisiologi Osteoartritis}

Pada keadaan normal, kartilago persendian berfungsi untuk menyerap tekanan pada persendian dan memberikan bantalan sehingga terjadi gerakan yang bebas gesekan antar tulang pada persendian (Petty, 2004: 140). Struktur utama kartilago adalah sel kartilago (chondrosit) dan matriks kartilago. Matriks terdiri atas air, proteoglikan dan kolagen (Cote, 2001: 496). Proteoglikan mengandung inti protein dengan rantai samping glikosaminoglikan. Proteoglikan utama pada kartilago adalah kondroitin sulfat dan keratin sulfat. yang berfungsi mendukung stabilitas dan kekuatan dari kartilago (Cote, 2001: 497). Dalam keadaan normal, matriks kartilago setiap saat berubah secara dinamis untuk mencapai keseimbangan. Pada kartilago terjadi proses remodeling secara berkesinambungan. Struktur matriks kartilago (kolagen dan proteoglikan) secara teratur dirombak oleh enzim autolitik dan diperbarui oleh sel kartilago (chondrosit) (Cote, 2001: 497).

Pada prinsipnya, pada OA terjadi kerusakan atau kehilangan struktur kartilago persendian. Kerusakan tersebut dikarenakan tekanan mekanis yang berlebihan pada sendi atau dan terjadi abnormalitas proses remodeling struktur sendi (Petty, 2004: 142). Sebagai respons dari tekanan mekanis, pada persendian, terjadi erosi struktur kartilago dengan atau tanpa didani pembentukan tonjolan tulang (osteofit) pada daerah subchondral (Ross, 1997: 22). Persendian yang sering mengalami OA biasanya merupakan persendian yang menumpu berat tubuh (weight-bearing joints).

\footnotetext{
Fisioterapi dan Terapi Latihan Pada Osteoarthritis (Novita Intan Arovah)
} 
Proses OA yang terjadi bersifat lokal, progresif, dan kronis. Proses pada OA terjadi secara progresif karena pada keadaan ini terjadi ketidakseimbangan antara proses katabolisme dan perbaikan kartilago. Pada OA, matriks kartilago yang terbentuk lebih lemah secara biomekanis sehingga lebih rentan terhadap cedera dan kerusakan lanjut (Beckerman et al., 1993: 73).

Secara histologis, proses kerusakan strukur kartilago pada OA disebabkan oleh trauma mekanis yang dapat menimbulkan cedera pada sel chondrosit (Ross, 1997: 24). Chondrosit mengadakan respons dengan mengeluarkan enzim proteolitik seperti protease, cathepsin, collagenase dan metalloprotease. Enzim-enzim ini mengubah matriks kartilago, membentuk struktur yang lebih kecil, menurunkan kekentalan matriks yang akhirnya menurunkan kemampuan biomekanis kartilago (Ross, 1997: 25). Kecepatan pengeluaran enzim dan katabolisme matriks pada OA jauh melampau proses yang terjadi pada sendi normal.

Proses perubahan kemampuan biomekanik kartilago menurunkan kemampuan sendi untuk menyangga karena terjadi peningkatan transmisi gaya pada chondrosit dan daerah subcondral (Ross, 1997: 25). Chondrosil yang mengalami cedera melepaskan lebih banyak enzim sedangkan daerah subcondral dapat mengalami micro-fracture yang dapat menimbulkan kekakuan dan penurunan elastisitas. Beberapa produk sekunder hasil perombakan chondrosit dan proteoglikan dapat mencetuskan peradangan pada sel-sel sinovial, lekosit polymorphonuclear dan macrophage sehingga dapat menimbulkan peradangan pada keseluruhan persendian (Cote, 2001: 496).

MEDI KORA Vol.III, No 1, April 2007:18-41 


\section{Epidemiologi Osteoartritis}

OA merupakan penyebab utama disabilitas persendian dan tercatat pada sepuluh besar daftar penyakit dunia yang dikeluarkan oleh WHO (Cote, 2001: 496). Faktor epidemiologis yang meningkatkan risiko OA antara lain: cedera sendi, penggunaan sendi yang berlebihan, dan obesitas. Cedera sendi yang terjadi pada usia di atas 35 tahun lebih berisiko untuk menimbulkan OA dibandingkan dengan cedera pada usia remaja (Saxon $e t$ al., 1999: 124). Aktivitas fisik dengan intensitas tinggi juga dapat meningkatkan risiko terjadinya OA. Pada keadaan ini diduga terjadi microtrauma dan degenerasi kartilago persendian yang kemudian mencetuskan OA (Saxon et al., 1999: 124). Obesitas meningkatkan risiko timbulnya OA sekaligus mempercepat proses degenerasi sendi pada OA. Pada umumnya sendi yang sering mengalami OA adalah sendi lutut (Cote, 2001: 496). Pada keadaan ini pengurangan berat badan dan pembatasan konsumsi lemak jenuh dapat mengurangi derajat OA. Hal ini dikarenakan lemak jenuh berhubungan dengan pembongkaran kartilago persendian (Cote, 2001: 496). Faktor risiko untuk terjadinya OA secara lengkap terdapat pada tabel 1 .

Fisioterapi dan Terapi Latihan Pada Osteoarthritis (Novita Intan Arovah) 
Tabel 1. Faktor Risiko Osteoartritis

\begin{tabular}{|l|l|}
\hline \multicolumn{1}{|c|}{ Jenis Faktor Risiko } & \multicolumn{1}{|c|}{ Contoh Faktor Risiko } \\
\hline Genetik & $\begin{array}{l}\text { Jenis kelamin (lebih sering terjadi pada } \\
\text { wanita) } \\
\text { Penyakit kolagen (Stickler`s syndrome) } \\
\text { Ras (lebih sering terjadi pada ras negroid) }\end{array}$ \\
\hline Non Genetik & $\begin{array}{l}\text { Umur (lebih sering pada usia }>40 \text { tahun) } \\
\text { Obesitas } \\
\text { Cedera persendian }\end{array}$ \\
\hline Lingkungan & $\begin{array}{l}\text { Pekerjaan yang menimbulkan stress } \\
\text { repetitive pada persendian } \\
\text { Tekanan yang berlebihan pada persendian }\end{array}$ \\
\hline
\end{tabular}

Dikutip dari Cote, (2001:497)

\section{Kriteria Diagnosis Osteoartritis}

Nyeri dan rasa kaku pada sendi merupakan gejala utama yang dikeluhkan penderita OA. Selanjutnya biasanya terjadi penurunan range of motion (ROM) persendian (Ross, 1997: 25). Kriteria diagnosis osteoartritis secara klinis tercantum pada tabel 2 . 
Tabel 2. Kriteria Diagnosis Osteoartritis

\begin{tabular}{|l|l|}
\hline Gejala Utama & Gejala Tambahan (minimal 3) \\
\hline Nyeri pada sendi & - Kaku sendi pagi hari kurang dari 30 \\
& menit \\
- Krepitasi sendi (suara tulang pada & perabaan) \\
- Sendi mengeras \\
- Pembesaran sendi \\
- Pengurangan jangkauan sendi (ROM) \\
- Daerah persendian tidak teraba \\
hangat \\
- Usia lebih dari 50 tahun \\
\hline
\end{tabular}

Dikutip dari Cote,(2001:497)

\section{FISIOTERAPI PADA OSTEOARTHRITHIS}

Fisioterapi merupakan manajemen rehabilitasi fisik dengan menggunakan berbagai modalitas fisik (Cote, 2001: 495-499). Secara garis besar, modalitas fisioterapi yang sering dipergunakan antara lain berupa: (1) thermal dan hydrotherapy, (2) electromagnetic therapy, dan (3) manual therapy (Beckerman et al., 1993: 73-77).

Fisioterapi dan Terapi Latihan Pada Osteoarthritis (Novita Intan Arovah) 


\section{Thermal dan Hydrotherapy}

Beberapa jenis terapi thermal yang sering dipergunakan antara lain: cryotherapy, wax bath, contrast bath dan hot packs. Selain itu terdapat juga hydrotherapy yang dikombinasikan dengan terapi latihan. Kombinasi tersebut dilakukan mengingat adanya gaya buoyancy pada air yang dapat mengurangi pengaruh gravitasi sehingga mempermudah gerakan sehingga dapat meminimalkan rasa nyeri akibat pergerakan.

Cryotherapy dapat dilakukan dengan memberikan aplikasi es pada daerah yang mengalami gangguan selama satu sampai tiga menit. Suhu kulit pada daerah tersebut dapat berkurang sebesar $10^{\circ} \mathrm{C}$. Aplikasi es dapat dilakukan dengan menggunakan handuk es, ice packs atau pemijatan dengan batang es. Pada prinsipnya terapi ini bertujuan untuk menurunkan tingkat metabolisme pada daerah tersebut sehingga cocok dilakukan pada keadaan akut. Terapi ini bisa mengatasi rasa nyeri, spasmus otot setelah kontraksi otot yang berlebihan, gangguan saraf atau pascaoperasi. Kontraindikasi terapi adalah gangguan kardiovaskular dan saraf terutama saraf sensoris. Manfaat khusus terapi ini adalah untuk menghentikan perdarahan (Petty, 2004: 142).

Wax bath merupakan teknik fisioterapi dengan menggunakan lilin parafin cair yang bersuhu $40^{\circ} \mathrm{C}$ sampai dengan $44^{\circ} \mathrm{C}$. Parafin tersebut diaplikasikan pada daerah persendian untuk mengurangi nyeri dan kekakuan persendian lengan dan kaki selama 30 sampai 45 menit. Selain mengurangi kekakuan dan nyeri, terjadi pula efek relaksasi sendi dan perbaikan kondisi

MEDIKORA Vol.III, No 1, April 2007:18-41 
dan kelembaban kulit. Kontraindikasi terapi ini adalah pada luka terbuka, luka bakar maupun infeksi kulit (Beckerman et al., 1993: 73-77).

Contrast bath dilakukan dengan mengkombinasikan air hangat dan dingin secara bergantian. Suhu air hangat dijaga pada kisaran $40^{\circ} \mathrm{C}$ sampai $45^{\circ} \mathrm{C}$ sedangkan suhu air dingin sekitar $15^{\circ} \mathrm{C}$ sampai $20^{\circ} \mathrm{C}$. Terapi ini terutama cocok dilakukan pada kondisi nyeri pada ekstremitas. Manfaat utama lain adalah memberikan efek relaksasi secara umum sehingga dapat menurangi rasa lelah paska aktivitas fisik yang berlebihan. Kontra-indikasi terapi ini adalah pada keadaan penurunan sensasi saraf sensoris misalnya pada stadium akhir diabetes mellitus (Petty, 2004: 150).

Hot packs biasanya terdiri atas silicate gel yang bernama bentonite. Hot packs ini dilarutkan pada tangki air khusus dan dapat meningkatkan suhu air menjadi $75^{\circ} \mathrm{C}$ sampai $80^{\circ} \mathrm{C}$. Panas yang timbul dari hot packs ini dipergunakan untuk mengurangi nyeri dan menimbulkan relaksasi. Terapi ini cocok dilakukan untuk mengatasi nyeri otot dan keadaan yang memerlukan relaksasi umum. Kontraindikasi dari terapi ini adalah luka terbuka, luka bakar dan penurunan sensasi saraf sensoris (Cote, 2001: 495).

\section{Electromagnetic Therapy}

LASER (Light Amplification Stimulated Emission of Radiation) therapy pada biasanya dikombinasikan dengan infra merah. Alat yang dipergunakan biasanya adalah helium neon LASER. Terdapat dua jenis aplikasi yakni yang berupa kontak langsung pada kulit dan yang tidak langsung (sekitar $5 \mathrm{~cm}$ dari kulit). Terapi dilakukan untuk mengurangi

\footnotetext{
Fisioterapi dan Terapi Latihan Pada Osteoarthritis (Novita Intan Arovah)
} 
nyeri, mempercepat penyembuhan luka terbuka, luka paska operasi dan komplikasi luka pada penderita diabetes. Terapi ini dikontraindikasikan pada penderita epilepsi, penderita gangguan kardiovaskular, dan orang yang menggunakan alat pacu jantung. Pada terapi ini baik fisioterapis maupun pasien harus menggunakan pelindung mata (Cote, 2001: 495).

Ultraviolet therapy merupakan terapi yang menggunakan gelombang ultraviolet dengan panjang gelombang 3900 sampai $1849 \mathrm{~A}^{\circ}$. Sumber gelombang ultraviolet adalah sinar matahari, lampu merkuri, dan lampu fluorosent. Terapi ini bermanfaat pada penderita vitamin $D$ deficiency, orang dengan penurunan berat badan drastis, penyakit kulit (psoriasis) dan kebotakan (alopesia). Manfaat terapi ini adalah untuk meningkatkan kadar vitamin D serum dan meningkatkan daya tahan terhadap infeksi. Kontraindikasi terapi ini adalah penderita dengan kulit yang sensitif, dermatitis, demam, tuberkulosis, dan kanker. Hal yang perlu diperhatikan pada terapi ini adalah kulit yang terbakar dan kemerahan dan radang pada selaput mata (Cote, 2001: 497).

Infra red therapy merupakan terapi menggunakan sinar infra merah dengan mempergunakan generator infra merah luminous dan non-luminous. Terapi ini digunakan untuk mengurangi nyeri dan kaku otot. Kontraindikasi terapi ini adalah gangguan peredaran darah, penurunan sensasi sensoris dan penurunan volume darah atas sebab apa pun. Hal yang perlu diwaspadai pada terapi ini adalah risiko kulit yang terbakar, sakit kepala, dan cedera pada mata (Cote, 2001: 498).

MEDIKORA Vol.III, No 1, April 2007:18-41 
Ultra sound therapy merupakan terapi dengan mempergunakan gelombang suara dengan frekuensi antara 500.000 sampai 3.000 .000 siklus/detik. Ultra sound dihasilkan oleh getaran dari kristal tertentu. Pada stadium awal aplikasi ultra sound dilakukan selama 3 sampai dengan 4 menit sedangkan pada stadium lanjut dilakukan selama 6 sampai dengan 8 menit. Terapi ini cocok digunakan pada peradangan sendi siku (tennis elbow), nyeri plantar (plantar fascitis), pemendekan otot dan ligamentum, peradangan tendon, sprain ligamentum, dan luka menahun. Manfaat terapi ini adalah untuk menghilangkan nyeri dan mempercepat penyembuhan luka. Kontraindikasi terapi ini adalah terapi pada daerah sekitar mata, telinga, ovarium, testis dan uterus wanita hamil dan area dengan vaskularisasi minimal (misalnya daerah perifer pada stadium lanjut diabetes) dan kanker. Hal yang perlu diperhatikan pada terapi ini adalah kemungkinan terjadinya luka bakar dan cavitation ( kerusakan pada tulang) (Brukner et al., 2007: 256).

Microwave diathermy merupakan terapi dengan mempergunakan panjang gelombang antara gelombang infra merah dan short wave diathermic waves. Panas yang diperoleh dari gelombang ini dapat digunakan untuk mengurangi nyeri. Gelombang diathermy diperoleh dengan memanaskan alat yang bernama magnetron. Output di transmisikan ke saluran kecil dan gelombang mikro dikeluarkan dengan frekuensi 2.450 siklus/detik dengan panjang gelombang $12,25 \mathrm{~cm}$. Terapi ini cocok diterapkan pada nyeri, infeksi bakteri, dan abses. Manfaat terapi ini adalah untuk meningkatkan sistem pertahanan tubuh dan membantu relaksasi.

Fisioterapi dan Terapi Latihan Pada Osteoarthritis (Novita Intan Arovah) 
Kontraindikasi terapi ini adalah kanker, tuberkulosis tulang, penggunaan sinar $\mathrm{X}$, dan gangguan sirkulasi darah. Hal yang perlu diwaspadai adalah luka bakar dan cedera pada mata (Beckerman et al., 1993: 73-77).

Short wave diathermy therapy merupakan terapi dengan mempergunakan arus listrik dengan frekuensi 27.120.000 siklus/detik dengan panjang gelombang 11 meter. Metode aplikasi yang dilakukan adalah dengan condenser field method dan cable method. Metode ini cocok digunakan untuk mengatasi peradangan nyeri sendi bahu, sendi siku (tennis elbow), degenerasi cervical (cervical spondilosis), osteoartritis, sprain ligament, nyeri punggung bawah (low back pain), nyeri pada tumit (plantar fascitis) dan sinusitis. Kontraindikasi terapi ini adalah demam, tekanan darah yang berfluktuasi, kulit sensitif, penderita epilepsi, orang dengan alat pacu jantung, gangguan ginjal dan hati, wanita hamil, tuberkulosis tulang, dan kanker (Beckerman et al., 1993: 73-77).

Functional electrical stimulation (FES) merupakan jenis terapi dengan mempergunakan arus frekuensi rendah. Stimulasi listrik dilakukan untuk mengaktifkan dan melatih otot yang kehilangan fungsi kontraksi akibat gangguan saraf. Terdapat dua jenis metode FES yakni menggunakan arus modified galvanic dan surged faradic. Pada metode dengan modified galvanic, terapi dilakukan dalam jangka waktu lama secara terus menerus. Waktu aplikasinya adalah antara 10 sampai dengan 200 milli detik dengan frekuensi 50 sampai dengan 100 denyut/detik. Metode ini dilakukan pada kerusakan saraf berat. Metode dengan arus surged faradic dilakukan dengan durasi yang lebih pendek ( 0,1 sampai dengan 1 milidetik) dan frekuensi 
yang lebih rendah (50 siklus/detik). Metode ini dilakukan pada kerusakan saraf parsial atau kompresi saraf. Metode ini bermanfaat untuk memperbaiki kerusakan saraf dan mengaktifkan kembali fungsi otot. Kontraindikasi dari terapi ini adalah luka terbuka, patah tulang, penggunaan plate logam pada fraktur, dan infeksi kulit (Beckerman et al., 1993: 73-77).

\section{Manual Therapy}

Terapi massage menggunakan rabaan untuk memberikan tekanan pada kulit, otot, tendo, dan ligamen. Pada dasarnya massage dipergunakan untuk mengurangi ketegangan otot, meningkatkan aliran darah, dan mengurangi kepekaan saraf terhadap nyeri. Jenis aplikasi massage yang biasa dilakukan antara lain: stroking, effleurage, kneading, picking up. dan wringing. Stroking dilakukan dengan keseluruhan tangan atau jari. Tangan tersebut dalam kondisi rileks dan memberi tekanan yang berirama sehingga dapat merileksasikan otot penderita. Eufleurage dilakukan dengan memberikan tekanan sekaligus menggerakkan tangan dengan kecepatan tertentu untuk mengurangi ketegangan otot sekaligus meningkatkan aliran darah limfe. Kneading merupakan aplikasi tekanan yang dilakukan dengan diikuti periode pelepasan secara bergantian. Picking up merupakan teknik massage dengan mengangkat massa otot dan segera melepaskannya kembali. Wringing merupakan teknik mengangkat masa otot kemudian memutarnya sebelum dilepaskan kembali (Moraska, 2005: 371).

Relaxed passive movement merupakan terapi yang dilakukan oleh fisioterapis dengan jalan menggerakkan otot dan persendian pasien secara

Fisioterapi dan Terapi Latihan Pada Osteoarthritis (Novita Intan Arovah) 
pasif. Terapi ini dilakukan untuk mendapatkan jangkauan gerak secara maksimal pada sendi, menimbulkan efek relaksasi secara umum, mengaktifkan kembali otot yang selama ini pasif, dan meningkatkan drainase limfe. Terapi ini terutama bermanfaat pada gangguan persendian (osteoartritis), stroke, kelumpuhan, dan orang yang harus melakukan istirahat total. Apabila diperlukan terapi ini dapat dikombinasikan dengan manual training (Moraska, 2005: 372).

Manual training dilakukan dengan tujuan spesifik seperti berjalan. Pada terapi ini dilakukan latihan agar pasien dapat mempergunakan alat bantu jalan sampai pada akhirnya dapat berjalan tanpa bantuan alat bantu. Terapi ini cocok dilakukan pada penderita yang baru saja mengalami amputasi kaki, pasca-stroke, kelumpuhan, gangguan persendian, parkinson, dan ataxia. Terapi keseimbangan dilakukan untuk melatih keseimbangan pada saat berjalan dan duduk (Deyle et al., 2000: 175).

\section{TERAPI LATIHAN PADA REHABILITASI OSTEOARTHRITHIS}

Terapi latihan yang direkomendasikan untuk penderita osteoartritis meliputi latihan fleksibilitas, latihan kekuatan (lokal), dan latihan aerobik (general). Latihan kekuatan meliputi jenis isometrik, isotonik, isokinctik. konsentrik dan eccoconcentric. Jenis latihan aerobik yang direkomendasikan adalah berjalan, berenang, yoga, dan Tai Chi (Deyle et al., 2000: 173-181). Latihan kekuatan bermanfaat pada jangka pendek (misalnya pengurangan nyeri) sedangkan efek latihan aerobik bermanfaat untuk meningkatkan fungsi persendian dalam jangka waktu yang lebih

MEDIKORA Vol.III, No 1, April 2007:18-41 
panjang. Program latihan harus bersifat individual dan harus berpusat pada pasien dengan mempertimbangkan aspek-aspek seperti usia, keadaan penyerta, dan minat dari penderita (Vad et al., 2002: 729-739)

Secara keseluruhan, program latihan pada osteoartritis meliputi lima tahap. Tahap I meliputi mobilisasi terkontrol untuk mengatasi nyeri. Tahap II dan III dilakukan dengan latihan bersifat open kinetic-chain sampai dengan closed kinetic-chain pada sendi yang mengalami artritis. Tahap IV difokuskan pada olahraga spesifik untuk meningkatkan koordinasi neuromuskular dan meneruskan latihan jenis closed kinetic chain. Pada tahap V (fase pemeliharaan) dilakukan edukasi kepada penderita untuk mengurangi risiko terjadinya cedera kembali dan memotivasi penderita agar tetap melakukan latihan rutin (Vad et al., 2002: 735). Berikut ini contoh tahapan terapi latihan pada penderita osteoartritis lutut.

\section{Latihan Tahap I}

Pada tahap ini tujuan utama terapi latihan adalah untuk memulihkan jangkauan sendi dan mengatasi penurunan kontrol motorik dan kekuatan otot kuadrisep. Hal yang perlu dicatat adalah, pada tahap ini latihan harus dilakukan dengan intensitas rendah untuk menghindari nyeri dan proses radang akut yang berkelanjutan (Vad et al., 2002: 735). Pada tahap ini perlu ditingkatkan fleksibilitas dan elastisitas jaringan sekitar persendian dan otot yang menunjang persendian untuk meningkatkan jangkauan sendi sekaligus mencegah terjadinya cedera yang berkepanjangan. Otot-otot utama yang menyusun lutut antara lain: hamstrings, kuadriceps, dan otot

Fisioterapi dan Terapi Latihan Pada Osteoarthritis (Novita Intan Arovah) 
gastroknemius-soleus(Petty, 2004: 155). Contoh latihan yang dapat dilakukan untuk meningkatkan fleksibilitas dan kekuatan otot yang mendukung kekuatan persendian lutut dapat dilihat pada gambar 1 .

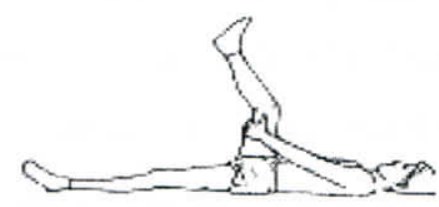

(a) Dynamic hamstring stretch

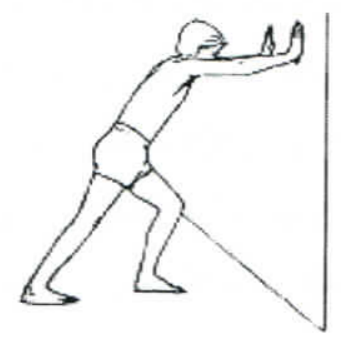

(c) gastrocnemius stretch

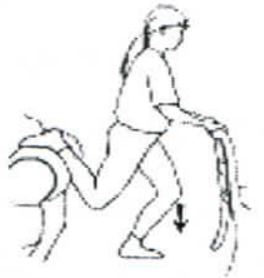

(b) quadriceps stretch;

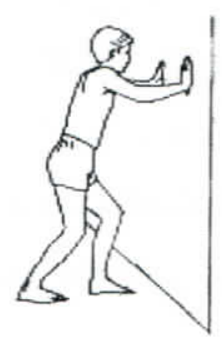

(d) soleus stretch.

\section{Gambar 1. Contoh Latihan Tahap I pada Osteoartritis Lutut}

\section{Latihan Tahap II}

Pada tahap II dilakukan latihan jenis open kinetic chain tanpa pembebanan untuk melatih kembali otot yang mendukung sendi lutut (Vad et al., 2002: 735). Latihan untuk otot kuadriceps diawali dengan latihan kontraksi isometrik pada posisi duduk dan latihan elevasi kaki pada posisi duduk untuk memberikan pembebanan pada otot kuadrisep. Apabila latihan tersebut sudah dapat dilakukan tanpa extensor lag (fleksi lutut) selama

MEDIKORA Vol.III, No 1, April 2007:18-41 
elevasi kaki, latihan dapat diteruskan dengan pembebanan di atas lutut untuk melatih kekuatan otot kuadrisep. Program latihan ini efektif untuk mengisolasi otot kuadrisep akan tetapi dikontraindikasikan pada penderita osteoartritis patello-femoral (Baker, 2000: 216-224). Jangkauan sendi yang aman pada latihan open-chain kinetik adalah ekstensi lutut $90^{\circ}$ sampai dengan $40^{\circ}$ (Vad et al., 2002: 736).
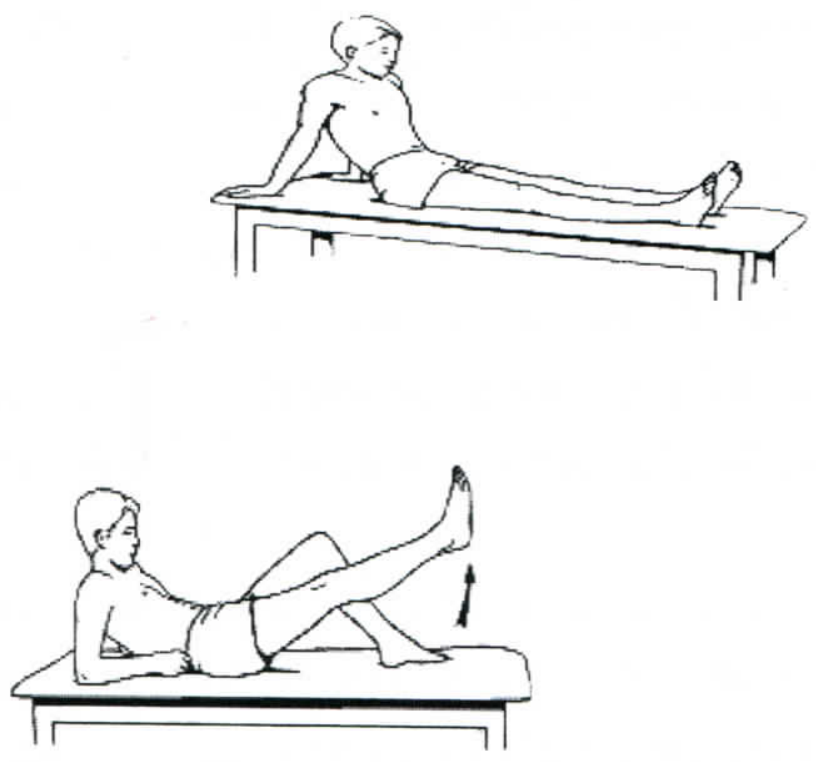

$\begin{array}{ll}\text { (a) quadriceps setting; } & \text { (b) straight leg raises. }\end{array}$

Gambar 2. Contoh Latihan Tahap II pada Osteoartritis Lutut

\section{Latihan Tahap III}

Pada tahap III, latihan yang dilakukan berjenis closed kinetic-chain (Vad et al., 2002: 738). Prinsip latihan tersebut adalah memfiksasi bagian distal persendian sedangkan bagian proksimal digerakkan memutari sumbu

Fisioterapi dan Terapi Latihan Pada Osteoarthritis (Novita Intan Arovah) 
(Hoeksma et al., 2004: 722-729). Jangkauan yang paling aman pada latihan closed kinetic-chain adalah sampai dengan fleksi $60^{\circ}$. Pada saat latihan, dapat dilakukan perabaan sendi lutut untuk melihat ada tidaknya tanda krepitasi pada sendi lutut sebagai ciri artritis patello-femoral (Petty, 2004: 150). Apabila ditemukan adanya krepitasi, jangkauan gerak harus disesuaikan. Latihan closed kinetic-chain bermanfaat untuk meningkatkan keseimbangan dan kemampuan propioseptor (Vad et al., 2002: 729-739). Latihan leg press biasanya dilakukan sebagai latihan pembuka (gambar 3a). Apabila pasien sudah mampu mengangkat paling tidak separuh dari berat badannya pada posisi leg press, latihan dapat ditingkatkan dengan mini-squat dan step down sampai dengan $40^{\circ}$ (Gambar 3b). Hal yang harus diperhatikan adalah pada tahap ini pembebanan dan peningkatan jangkauan sendi harus dilakukan secara bertahap untuk melindungi sendi lutut dari cedera berulang.

Latihan proprioceptor dilakukan dengan latihan bertumpu pada satu kaki pada lempeng yang tidak stabil dengan mata terbuka, tertutup kemudian ditambah dengan tantangan multidireksional (gambar 3c). Setelah latihan tersebut dapat dikuasai, dapat dilakukan latihan 'pro-fitter' yang efektif untuk melatih stabilitas lateral dan medial dan koordinasi (gambar 3d). Latihan yang selanjutnya dapat dilakukan adalah latihan sepeda statis (Baker, 2000: 220). Hal ini perlu dilakukan karena kartilago memerlukan gerakan teratur (kompresi dan dekompresi) untuk memicu terjadinya remodeling secara aktif. Latihan ini perlu dilakukan pada tiga hari dalam seminggu selama 20 sampai dengan 30 menit yang sekaligus juga bertujuan

MEDIKORA Vol.III, No 1, April 2007:18-41 
untuk meningkatkan ketahanan sistem kardiovaskular dan meningkatkan kekuatan otot kuadrisep dan hamstrings (Baker, 2000: 216-224).

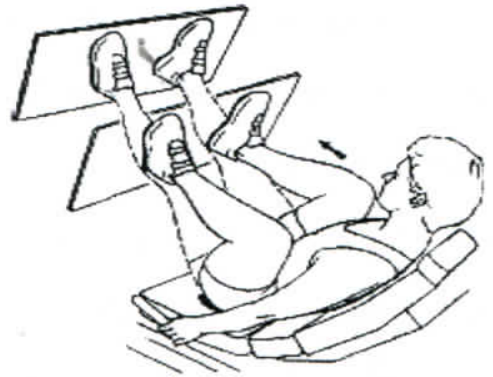

(a). leg press.

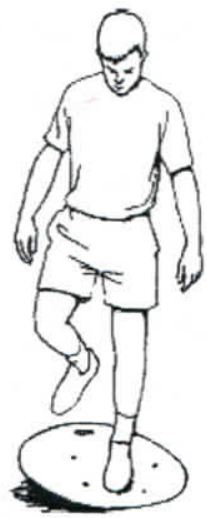

(c). balance board.

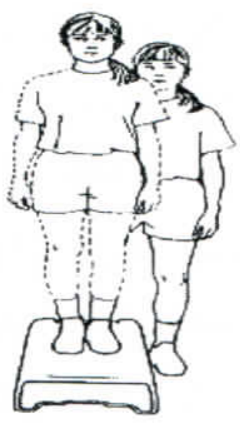

(b) lateral step down.

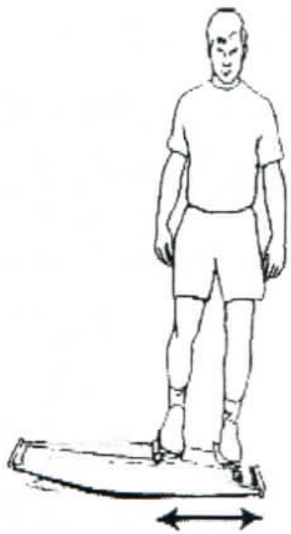

(d).lateral 'pro-fitter'

\section{Gambar 3. Contoh Latihan Tahap III pada Osteoartritis Lutut}

\section{Latihan Tahap IV}

Pada tahap IV pasien diharapkan dapat kembali melakukan aktivitas fisik seperti sebelum terjadinya cedera (osteoartritis) dengan risiko cedera ulang yang minimal (Vad et al., 2002: 738). Pada fase ini dilakukan latihan

Fisioterapi dan Terapi Latihan Pada Osteoarthritis (Novita Intan Arovah) 
konsentrik dan eksentrik pada suatu program latihan closed kinetic chain dengan pembebanan minimal pada persendian yang mengalami osteoartritis (Baker, 2000: 223). Tahap ini dimulai apabila pasien paling tidak sudah memiliki jangkauan sebesar $120^{\circ}$, mampu melakukan gerakan berjalan secara normal, mampu menaiki dan menuruni tangga, dan mampu berlari tanpa mengalami nyeri (Baker, 2000: 223). Contoh jenis latihan untuk menguji kesiapan atlet untuk kembali pada aktivitas semula dapat dilihat pada gambar 4. Gambar 4 a merupakan latihan lari mengelilingi lintasan berbentuk angka 8 dan latihan cariokas (gerakan pada lintasan besar ke kecil dan dari kecepatan lambat ke tinggi). Kedua jenis latihan ini berfungsi untuk meningkatkan sekaligus menguji kemampuan sendi lutut untuk beradapatasi pada gerakan lengkung tanpa memotong gerakan dan tanpa mengurangi kecepatan.

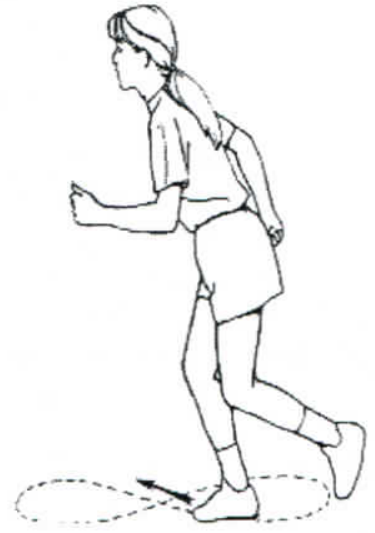

(a) agility drills (figure-eights)

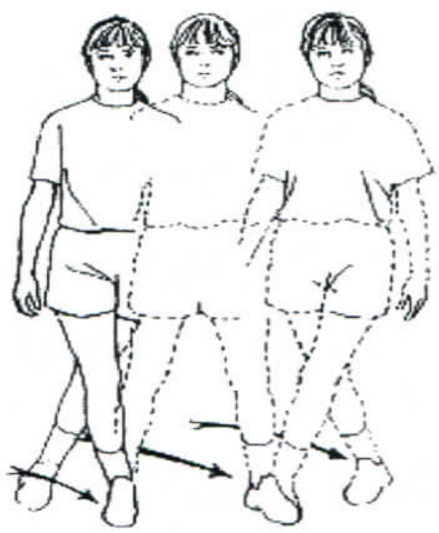

(b) cariokas

Gambar 4. Contoh Latihan Tahap IV pada Osteoartritis Lutut

MEDIKORA Vol.III, No 1, April 2007:18-41 


\section{Latihan Tahap V}

Tujuan utama latihan tahap $\mathrm{V}$ adalah mempertahankan level aktivitas pada tahap IV sehingga kekuatan otot pendukung sendi menjadi optimal dan mengurangi risiko terjadinya cedera ulangan (Vad et al., 2002: 729-739). Latihan harus dilakukan 2 sampai 3 kali dalam seminggu dengan melibatkan jenis latihan yang dapat meningkatkan keseimbangan, kekuatan, fleksibilitas, ketahanan, dan kemampuan propioseptor otot.

Tabel 3. Rangkuman Rekomendasi Terapi Latihan pada Penderita Osteoartritis Lutut

\begin{tabular}{|c|c|c|c|}
\hline 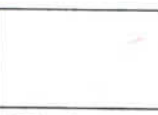 & Latihan Kekuatan & Latihan Aerobik & $\begin{array}{l}\text { Latihan } \\
\text { Fleksibilitas }\end{array}$ \\
\hline Tujuan & $\begin{array}{l}\text { Meningkatkan } \\
\text { kekuatan otot } \\
\text { kuadrisep, } \\
\text { Menyeimbangkan } \\
\text { kekuatan otot } \\
\text { kuadrisep dengan } \\
\text { kekuatan otot lain } \\
\text { pada kelompok otot } \\
\text { ekstremitas bawah }\end{array}$ & $\begin{array}{l}\text { Meningkatkan } \\
\text { ketahanan } \\
\text { kardiovaskular. }\end{array}$ & $\begin{array}{l}\text { Meningkatkan } \\
\text { jangkauan gerak } \\
\text { sendi. }\end{array}$ \\
\hline $\begin{array}{l}\text { Jenis } \\
\text { latihan }\end{array}$ & $\begin{array}{l}\text { - Isotonik } \\
\text { ekstensi kaki, } \\
\text { squats, menaiki } \\
\text { tangga dll } \\
\text { - Isometrik (pada } \\
\text { keadaan nyeri) } \\
\text { menaik-turunkan } \\
\text { kaki dalam } \\
\text { keadaan lurus }\end{array}$ & $\begin{array}{l}\text { Berjalan } \\
\text { Latihan dalam air } \\
\text { (apabila berjalan } \\
\text { menimbulkan } \\
\text { nyeri) }\end{array}$ & $\begin{array}{l}\text { Penguluran setiap } \\
\text { otot utama pada } \\
\text { latihan kekuatan } \\
\text { dan aerobik }\end{array}$ \\
\hline
\end{tabular}

Fisioterapi dan Terapi Latihan Pada Osteoarthritis (Novita Intan Arovah) 


\begin{tabular}{|c|c|c|c|}
\hline Frekuensi & $\begin{array}{l}\text { Dua kali seminggu } \\
\text { (dapat } \\
\text { dikombinasikan } \\
\text { dengan latihan } \\
\text { aerobik pada hari } \\
\text { yang bergantian) }\end{array}$ & $\begin{array}{l}\text { Dua kali seminggu } \\
\text { (dapat } \\
\text { dikombinasikan } \\
\text { dengan latihan } \\
\text { kekuatan pada hari } \\
\text { yang bergantian) }\end{array}$ & $\begin{array}{lr}\text { Sebelum } & \\
\text { dilakukan latihan } \\
\text { kekuatan } \\
\text { aerobik. }\end{array}$ \\
\hline Intensitas & $\begin{array}{l}2 \text { set dengan } 12-15 \\
\text { kali repetisi }\end{array}$ & $\begin{array}{lr}40-60 \% & \text { dari } \\
\text { denyut } & \text { jantung } \\
\text { maksimal } & (220- \\
\text { usia }) & \end{array}$ & - \\
\hline
\end{tabular}

Dikutip dari Vad. et al (2002:738)

\section{KESIMPULAN}

Osteoartritis merupakan jenis radang sendi yang paling sering dijumpai. Osteoartritis terjadi sebagai konsekuensi akhir dari gangguan mekanis dan biologis pada kartilago persendian sehingga terjadi erosi kartilago dan pembentukan osteofit pada daerah subkondral. Diagnosis osteoartritis didasarkan pada riwayat perjalanan penyakit. pemeriksaan fisik. dan pemeriksaan radiologis. Manajemen osteoartritis dewasa ini mengkombinasikan terapi farmakologis dengan fisioterapi dan terapi latihan untuk meminimalkan penggunaan terapi bedah.

Fisioterapi sangat bermanfaat terutama pada stadium akut dan bertujuan untuk mengurangi nyeri dan respon peradangan. Short wave diathermy dan cold therapy merupakan dua modalitas fisioterapi yang terbukti sangat efektif pada rehabilitasi osteoartritis. Terapi latihan dilakukan secara bertahap dengan tujuan meminimalkan cedera dengan memperkuat otot pendukung sendi, memulihkan kekuatan dan jangkauan 
gerak agar dapat dilakukan aktivitas seperti semula. Latihan yang berkelanjutan diperlukan untuk meningkatkan keseimbangan, kekuatan, fleksibilitas, ketahanan dan kemampuan propioseptor otot yang pada akhirnya dapat mencegah terjadinya cedera yang berulang.

\section{DAFTAR PUSTAKA}

Baker, K. (2000). "An Update on Exercise Therapy for Knee Osteoarthritis." Nutrition in Clinical Care (Tahun 3, Nomor 4) Hlm.216-224.

Beckerman, H., L. M. Bouter, G. J. M. G. v. d. Heijden, R. A. D. Bie and B. W. Koes (1993). "Efficacy of Physiotherapy for Musculoskeletal Disorders : What Can We Learn from Research?" British Journal of General Practice (Tahun 43, Nomor 73-77.

Brukner, P. and K. Khan (2007). Clinical Sports Medicine. Sydney, McGraw-Hill.

Cote, L. G. (2001). "Management Osteoarthritis." Journal of the American Academy of Nurse Practitioners (Tahun 13, Nomor 11) HIm.495-499.

Deyle, G., N. Henderson, R. Matekel, M. Ryder, M. Garber and S. Allison (2000). "Effectiveness of Manual Physical Therapy and Exercise in Osteoarthritis of the Knee: A Randomized Controlled Trial." Annual Internal Medicine (Tahun 132, Nomor 173-181.

Hoeksma, H., J. Dekker, H. Ronday, A. Heering and F. Breedveld (2004). "Comparison of Manual Theraphy and Exercise Therapy in Osteoarthritis of the Hip: a Randomized Clinical Trial." Arthritis Rheumatology (Tahun 51, Nomor 5) Hlm.722-729.

Moraska, A. (2005). "Sports Massage : a Comprehensive Review." Journal Sports Medicine and Physical Fittness (Tahun 2005, Nomor 45) HIm.370-80.

Petty, N. J. (2004). Principles of Neuromusculoskeletal Treatment and Management: a Guide for Therapist. Edinburgh, Churchill Livingstone.

Fisioterapi dan Terapi Latihan Pada Osteoarthritis (Novita Intan Arovah) 
Ross, C. (1997). "A Comparison of Osteoarthritis and Rhematoid Arthritis: Diagnosis and Treatment." The Nurse Practitioner (Tahun 22, Nomor 9) HIm.20-30.

Saxon, L.j C. Finch and S. Bass (1999). "Sports Participation, Sports Injuries and Osteoarthritis." Sports Medicine (Tahun 28, Nomor 2) HIm.123-135.

Vad, V., H. M. Hong, M. Zazzali, N. Agi and D. Basrai (2002). "Exercise Recommendations in Athletes with Early Osteoarthritis of the Knee." Sports Medicine (Tahun 32, Nomor 11) HIm.729-739.

MEDIKORA Vol.III, No 1, April 2007:18-41 